Original Research Paper

\title{
The Correlations of Knowledge, Attitude and Practice with Compliance in Treatment of Pulmonary Tuberculosis Patients in Puskesmas Cakranegara
}

\author{
Auliana Puji Lestari ${ }^{1}$, Prima Belia Fathana ${ }^{1 *}$, Wahyu Sulistya Affarah ${ }^{1}$ \\ ${ }^{1}$ Program Studi Pendidikan Dokter, Fakultas Kedokteran Universitas Mataram, Mataram, Indonesia
}

\author{
Article History \\ Received : December 30 ${ }^{\text {th }}, 2020$ \\ Revised : January $06^{\text {th }}, 2021$ \\ Accepted : January $16^{\text {th }}, 2021$ \\ Published : January $20^{\text {th }}, 2021$ \\ *Corresponding Author: \\ Prima Belia Fathana, \\ Program Studi Pendidikan \\ Dokter, Fakultas Kedokteran \\ Universitas Mataram, Mataram, \\ Indonesia \\ Email: ninaalestari@gmail.com
}

\begin{abstract}
Patient compliance refers to the suitability of behavior against treatment recommendations include timing, dose and frequency of treatment. Compliance to tuberculosis treatment was actually very complex and dynamic with various factors that interacted each other, and therefore it will influence on patient's behavior decision. Patient who has a good compliance will increase success to his recovery. This study was carried out to determine the correlation between tuberculosis patient behavior which consists of the domain of knowledge, attitudes and practices with compliance to taking antituberculosis drugs at the Puskesmas Cakranegara commencing on July to November 2020. This research was an observational analytic study using a cross sectional method. Population sample was patients who diagnosed with pulmonary tuberculosis which undergoing category 1 treatment at Puskesmas Cakranegara. The data used in the study was primary data established from interviewing patients using a questionnaire on selected Pulmonary TB patients including respondents who eligible as the inclusion and exclusion criteria. The number of samples in this study were 30 infectedpeople. The data obtained were analyzed using the Spearman correlation test. The correlation test of the study showed that there was no significant correlation between variable of knowledge and medication compliance $(\mathrm{p}=$ $0.079, \mathrm{r}=0.325)$. However, the attitude variables had a significant correlation with medication compliance $(\mathrm{p}=0.000, \mathrm{r}=0.715)$. Similarly, the practices variable has a significant correlation to the medication compliance $(\mathrm{p}=0.000, \mathrm{r}=0.656)$. This study found that there was no significant correlation between knowledge and compliance taking anti-tuberculosis drugs. However, it was found that there was a significant correlation between attitudes and practices with compliance to taking anti-tuberculosis drugs.
\end{abstract}

Keywords: Attitude; Behavior; Compliance; Knowledge; Practice.

\section{Pendahuluan}

Tuberkulosis (TB) adalah salah satu penyakit menular yang masih menjadi masalah kesehatan masyarakat yang utama di seluruh dunia dengan menginfeksi sekitar seperempat dari populasi dunia. TB menjadi penyebab utama kematian setiap tahunnya dengan menginfeksi sekitar 10 juta orang dan sekitar 1,5 juta kematian terkait dengan TB dilaporkan pada tahun 2018 (WHO, 2019). Jumlah kasus TB di Indonesia yang dilaporkan pada tahun 2018 mencapai 845.000 kasus (WHO, 2019). Jumlah pasien TB pada tahun 2018 di Provinsi Nusa Tenggara Barat (NTB) mencapai 6.162 orang, dengan 4.367 orang merupakan kasus TB paru BTA (+). Case Notification Rate (CNR) yaitu jumlah kasus TB yang diobati dan dilaporkan di antara 100.000 penduduk di NTB pada tahun 2017 sebesar 134,12 dan mengalami penurunan pada tahun 2018 menjadi 123. Angka keberhasilan pengobatan penderita TB BTA (+), kasus baru di NTB pada tahun 2018 juga terjadi penurunan dibandingkan tahun 2017, yakni dari 87,75 menjadi 86,3\% (Dikes NTB, 2019).

Case Detection Rate (CDR) menggambarkan cakupan penemuan pasien baru BTA (+) pada wilayah tersebut. Menurut dinas kesehatan kota Mataram tahun 2019, 
mencatat kasus TB paru selama tahun 2017 sebanyak 337 kasus dari yang ditargetkan sebanyak 800 kasus TB paru sehingga dinilai relatif rendah (Dikes NTB, 2019). Puskesmas Cakranegara sebagai salah satu wilayah kerja Kota Mataram masuk dalam 3 besar wilayah sebagai penyumbang kasus TB terbesar di Kota Mataram. Pada tahun 2019 Angka Penemuan Kasus (CDR) pada wilayah kerja puskesmas Cakranegara tercatat $70 \%$ dari 234 kasus yang diperkiarakan. Target temuan kasus Tuberkulosis (TB) puskesmas Cakranegara tahun 2020 adalah 280 kasus dengan target kasus suspek sebesar 1.512.

TB menjadi tantangan kesehatan di Indonesia, tidak hanya karena tingginya angka mortalitas dan morbiditas, tetapi juga karena kesulitan dalam menangani kasus TB. Pengobatan TB membutuhkan setidaknya 6 bulan setiap hari tanpa henti. Selain itu, efek samping obat TB membuat pasien enggan minum obat. Hal ini akhirnya menghasilkan kepatuhan dan kualitas hidup yang rendah untuk pasien TB (Farhat et al., 2013; Pandia et al., 2019).

Faktor yang mempengaruhi perilaku seseorang saat menjalani pengobatan TB ditentukan dan dibentuk dari tiga faktor yaitu: 1) Predisposing factors (faktor-faktor predisposisi) yang terwujud dalam pengetahuan, sikap, kepercayaan, keyakinan dan nilai-nilai. 2) Enabling factors (Faktorfaktor pendukung), yang terwujud dalam fasilitas, sarana maupun prasarana kesehatan. 3) Reinforcing factors (Faktor-faktor Pendorong), yang terwujud dalam petugas kesehatan dan keluarga (Green \& Yan, 2018). Keberhasilan dalam pengobatan TB sangat bergantung dari perilaku kepatuhan penderita TB dalam mengonsumsi obatnya (Green \& Yan, 2018).

Benjamin Bloom (1908) dalam Notoatmodjo (2005), membagi perilaku manusia kedalam tiga domain, yaitu kognitif (cognitive), afektif (affective), dan psikomotorik (psychomotor). Teori ini dimodifikasi untuk pengukuran hasil pendidikan kesehatan, yakni pengetahuan (knowledge), sikap (attitude), dan tindakan (practice) (Notoatmodjo, 2005). Pada penelitian ini akan dibahas mengenai hubungan pengetahuan, sikap dan tindakan pasien TB paru dengan kepatuhan minum obat anti tuberculosis di Puskesmas Cakranegara kota Mataram, Nusa Tenggara Barat pada periode Juli hingga November 2020.

\section{Bahan dan Metode}

Penelitian ini merupakan penelitian analisis observasional dengan rancangan penelitian potong lintang atau cross sectional. Pengambilan data dilaksanakan dengan wawancara terpimpin menggunakan kuisioner via telepon. Populasi penelitian ini adalah pasien TB paru yang menjalani pengobatan kategori 1 di wilayah Puskesmas Cakranegara kota Mataram pada bulan Juli sampai November 2020 dengan jumlah subjek penelitian sebesar 30 orang.

Penelitian ini menggunakan metode pengambilan sampel dengan teknik non probability sampling tipe purposive sampling. Kriteria inklusi dalam penelitian ini adalah pasien TB paru yang menjalankan pengobatan di wilayah kerja puskesmas Cakranegara, usia pasien TB paru dewasa $\geq 18$ tahun, dan pasien TB paru dengan pengobatan kategori 1. Adapun kriteria eksklusi dalam penelitian ini adalah pasien TB paru yang putus obat, pasien TB paru dengan penyakit penyerta HIV, pasien TB paru dengan kehamilan, dan pasien TB paru anak.

Variabel bebas (independent variable) dalam penelitian ini adalah pengetahuan, sikap, dan tindakan penderita TB paru. Variabel tergantung (dependent variable) dalam penelitian ini adalah kepatuhan minum obat anti tuberkulosis pada penderita TB paru. Pada penelitian ini pengolahan data dilakukan dengan menggunakan aplikasi analisis statistic SPSS versi 24. Data yang diperoleh kemudian diolah dengan menggunakan metode uji non-parametrik Spearman untuk mengetahui adanya hubungan antara variabel independen dan dependen dengan tingkat kemaknaan $\alpha \leq 0,05$.

\section{Hasil dan Pembahasan}

Pada penelitian ini didapatkan 30 subjek penelitian yang memenuhi kriteria inklusi untuk dijadikan sampel dalam penelitian. Data yang digunakan merupakan data primer melalui wawancara menggunakan kuisioner. Adapun 
Lestari, AP et al. (2021). Jurnal Biologi Tropis, 21 (1): 65 - 71

DOI: http://dx.doi.org/10.29303/jbt.v21i1.2373

karakteristik subjek penelitian dapat dilihat pada tabel 1 .

Tabel 1. Karakteristik Umum Subjek Penelitian

\begin{tabular}{|l|l|c|c|}
\hline \multicolumn{2}{|c|}{ Variabel Karakteristik } & $\mathrm{N}$ & Persentase (\%) \\
\hline \multirow{4}{*}{ Jenis Kelamin } & Pria & 17 & 56.7 \\
\cline { 2 - 4 } & Wanita & 13 & 43.3 \\
\hline \multirow{5}{*}{ Usia } & $18-44$ tahun & 18 & 60 \\
\cline { 2 - 4 } & 45-65 tahun & 12 & 40 \\
\hline \multirow{5}{*}{ Pekerjaan } & Tidak sekolah & 3 & 10.0 \\
\cline { 2 - 4 } & SD & 7 & 23.3 \\
\cline { 2 - 4 } & Tamat SMP & 2 & 6.7 \\
\cline { 2 - 4 } & Tamat SMA & 14 & 46.7 \\
\cline { 2 - 4 } & Tamat sarjana & 4 & 13.3 \\
\hline & Tidak bekerja/IRT & 8 & 26.7 \\
\cline { 2 - 4 } & Petani & 6 & 20.0 \\
\cline { 2 - 4 } & Pegawai swasta & 3 & 10.0 \\
\cline { 2 - 4 } & Wiraswasta & 12 & 40.0 \\
\cline { 2 - 4 } & Dan lain lain & 20 & 3.3 \\
\hline \multirow{5}{*}{ Lama Pengobatan } & 2 minggu s/d 2 bulan & 10 & 66.66 \\
\cline { 2 - 4 } & $>2$ bulan s/d 6 bulan & - & 33.33 \\
\cline { 2 - 4 } & $>6$ bulan & 20 & - \\
\hline \multirow{5}{*}{ Fase Pengobatan } & Fase awal/ intensif & 10 & 66.66 \\
\cline { 2 - 4 } & Fase lanjutan & 33.33 \\
\hline
\end{tabular}

Karakteristik subjek penelitian berdasarkan jenis kelamin pria sebanyak 17 orang $(56.7 \%)$ dan wanita sebanyak 13 orang (43.3\%). Mayoritas subjek penelitian berada pada usia produktif yaitu 18 orang dengan rentang usia $18-44$ tahun $(60 \%)$ dan 12 orang dengan rentang usia 45-65 tahun (40\%). Berdasarkan pendidikan diperoleh mayoritas subjek tamat SMA (Sekolah Menengah Atas) yaitu sebanyak 14 orang (46.7\%). Berdasarkan pekerjaan, mayoritas subjek wiraswasta yaitu sebanyak 12 orang $(40 \%)$. Berdasarkan lama pengobatan mayoritas menjalankan pengobatan selama 2 minggu sampai dengan 2 bulan (fase awal) yaitu sebanyak 20 orang $(66.66 \%)$.

Tabel 2. Distribusi Frekuensi Sampel Berdasarkan Pengetahuan, Sikap, Tindakan, dan Kepatuhan

\begin{tabular}{|c|c|c|}
\hline Variabel & Jumlah (n) & Persentase (\%) \\
\hline \multicolumn{3}{|l|}{ Pengetahuan } \\
\hline Baik & 22 & 73.33 \\
\hline Cukup & 5 & 16.67 \\
\hline Kurang & 3 & 10 \\
\hline \multicolumn{3}{|l|}{ Sikap } \\
\hline Baik & 16 & 53.33 \\
\hline Cukup & 13 & 43.33 \\
\hline Kurang & 1 & 3.33 \\
\hline \multicolumn{3}{|l|}{ Tindakan } \\
\hline Baik & 17 & 56.67 \\
\hline Cukup & 10 & 33.33 \\
\hline Kurang & 3 & 10 \\
\hline \multicolumn{3}{|l|}{ Kepatuhan } \\
\hline Patuh & 21 & 70 \\
\hline Tidak patuh & 9 & 30 \\
\hline
\end{tabular}


Distribusi frekuensi sampel berdasarkan variabel pengetahuan (Tabel 2), mayoritas sampel yang memiliki pengetahuan baik berjumlah 22 orang $(73,33 \%)$. Mayoritas sampel berdasarkan variabel sikap yang baik berjumlah
16 orang $(53,33 \%)$. Meyoritas sampel berdasarkan variabel tindakan yang baik berjumlah 17 orang $(56,67 \%)$. Serta pada variabel kepatuhan, mayoritas sampel memiliki kepatuhan yang baik 21 orang $(70 \%)$.

Tabel 3. Korelasi Variabel dengan Kepatuhan Minum Obat pada Pasien Tuberkulosis Paru di Puskesmas Cakrenegara

\begin{tabular}{|c|c|c|c|c|}
\hline \multirow{2}{*}{ Variabel bebas } & \multicolumn{2}{|c|}{ Variabel terikat (Kepatuhan) } & \multirow{2}{*}{ p-value } & \multirow{2}{*}{$\mathrm{R}$} \\
\hline & Patuh & Tidak Patuh & & \\
\hline \multicolumn{5}{|l|}{ Pengetahuan } \\
\hline Baik & 17 & 5 & \multirow{3}{*}{0,079} & \multirow{3}{*}{0,325} \\
\hline Cukup & 4 & 1 & & \\
\hline Kurang & 0 & 3 & & \\
\hline \multicolumn{5}{|l|}{ Sikap } \\
\hline Baik & 16 & 0 & \multirow{3}{*}{0,000} & \multirow{3}{*}{0,625} \\
\hline Cukup & 5 & 8 & & \\
\hline Kurang & 0 & 1 & & \\
\hline \multicolumn{5}{|l|}{ Tindakan } \\
\hline Baik & 16 & 1 & \multirow{3}{*}{0,000} & \multirow{3}{*}{0,656} \\
\hline Cukup & 5 & 5 & & \\
\hline Kurang & 0 & 3 & & \\
\hline
\end{tabular}

p-value $=$ signifikansi $; \mathrm{R}=$ kekuatan korelasi .

Berdasarkan hasil uji analitik korelasi Spearman antara variabel pengetahuan dengan variabel kepatuhan didapatkan hasil yang tidak signifikan secara statistik $(\mathrm{p}=0,079)$. Nilai koefisien korelasi (r) sebesar 0,325 yang menunjukkan arah positif yang berarti semakin tinggi pengetahuan, maka semakin tinggi tingkat kepatuhan minum obat. Kekuatan korelasi menunjukkan korelasi lemah ( $\mathrm{r}=0,2$ sampai 0,4$)$.

Berdasarkan hasil uji analitik korelasi Spearman antara variabel sikap dengan variabel kepatuhan didapatkan hasil yang signifikan dan bermakna $(p=0,000)$. Nilai koefisien korelasi $(r)$ sebesar 0,715 yang menunjukkan arah positif yang berarti semakin tinggi sikap, maka semakin tinggi tingkat kepatuhan minum obat. Kekuatan korelasi menunjukkan korelasi yang kuat $(r=0,6$ sampai 0,8$)$.

Berdasarkan hasil uji analitik korelasi Spearman antara variabel tindakan dengan variabel kepatuhan pada penelitian ini didapatkan hasil yang signifikan dan bermakna $(p=0,000)$. Nilai koefisien korelasi $(r)$ sebesar 0,656 yang menunjukkan arah positif yang berarti semakin tinggi variabel tindakan, maka semakin tinggi tingkat kepatuhan minum obat. Kekuatan korelasi menunjukkan korelasi yang kuat ( $r=0,6$ sampai 0,8$)$. (Tabel 3).

\section{Pembahasan}

Pada uji hipotesis korelasi antara variabel pengetahuan dengan kepatuhan menunjukkan bahwa tidak terdapat korelasi yang bermakna. Hasil penelitian ini tidak sesuai dengan penelitian dari Green \& Yan (2018) yang menyatakan bahwa pengetahuan menjadi salah satu faktor predisposisisi untuk mencapai suatu perilaku patuh dalam pengobatan. Penelitian ini dapat dibandingkan dengan penelitian yang dilakukan oleh Mushtaq et al (2010) di Pakistan dengan jumlah subjek penelitian 1064 orang yang menunjukkan bahwa pengetahuan memiliki korelasi yang bermakna dengan kepatuhan. Pada penelitian lain yang dilakukan oleh Tachfouti. et al., (2012) di Afrika dengan subjek penelitian sebesar 290 pasien TB menunjukkan bahwa adanya hubungan yang signifikan antara pengetahuan dengan kepatuhan pengobatan TB.

Adanya perbedaan signifikansi korelasi pada penelitian ini dengan dua penelitian sebelumnya dapat dipengaruhi oleh beberapa faktor yang tidak diteliti dalam penelitian ini yang berkontribusi dan memberikan sumbangan yang lebih besar sehingga mempengaruhi 
kepatuhan. Kepatuhan terhadap pengobatan tuberkulosis begitu kompleks, fenomenanya dinamis dengan berbagai faktor yang saling berinteraksi satu sama lain, sehingga berdampak pada keputusan pemilihan perilaku (Notoatmodjo, 2005).

Faktor lain yang menyebabkan perbedaan signifikansi variabel pengetahuan dengan kepatuhan pada penelitian ini dengan dua penelitian sebelumnya juga dapat dikarenakan oleh faktor besar sampel penelitian. Dapat dilihat dari besar sampel penelitian pada dua penelitian sebelumnya jauh lebih besar dibandingkan jumlah sampel pada penelitain ini. Besar sampel penelitian akan mempengaruhi kekuatan signifikansi suatu data. Kriteria inklusi dan ekslusi pada penelitian ini juga dapat menjadi faktor perancu karena berpengaruh terhadap variabilitas distribusi data pada sampel penelitian (Pandia et al., 2019).

Hasil penelitian ini sesuai dengan penelitian yang dilakukan oleh Sari et al (2017) pada pasien TB paru rawat jalan di Jakarta, dimana dilakukan penelitian terhadap 33 orang yang mengkonsumsi obat anti tuberkulosis kategori 1 yang diobservasi pengobatannya selama 6-8 bulan. Hasil penelitian tersebut didapatkan hubungan yang tidak bermakna antara pengetahuan dengan kepatuhan ( $\mathrm{p}=$ 0,619). Tidak adanya hubungan pada penelitian ini dapat diakibatkan karena beberapa faktor yang sangat mempengaruhi kepatuhan yaitu peran PMO dan keluarga dalam pengobatan TB serta akses pelayanan kesehatan. Pada penelitian lain yang dilakukan oleh Mweemba. et al (2008) di Zambia dengan melibatkan 104 responden dewasa dengan rentang usia 18-66 tahun juga didapatkan tidak adanya hubungan yang bermakna antara pengetahuan dengan kepatuhan $(\mathrm{r}=0,12, \mathrm{p}=0,12)$. Penelitian ini mengatakan bahwa pengetahuan bukan merupakan determinan langsung terhadap kepatuhan, dimana sikap memediasi hubungan antara pengetahuan dan kepatuhan.

Pada uji hipotesis korelasi antara variabel sikap dengan kepatuhan menunjukkan bahwa terdapat korelasi yang bermakna. Penelitian ini dapat dibandingkan dengan penelitian yang dilakukan oleh Hendesa \& Yan (2018) di RS Paru Kota Palembang Tahun 2017. Penelitian ini merupakan penelitian deskriptif observasional yang dilakukan dari bulan Oktober-November dengan minimal sampel 62 orang. Dalam penelitian tersebut menunjukkan tidak terdapat hubungan yang signifikan antara sikap pasien TB Paru dengan kepatuhan berobat ( $p=0,213$ dan OR=1,909 (95\% CI: 0,687-5,305). Pada penelitian tersebut dijelaskan tidak adanya hubungan dapat terjadi akibat dari faktor ekonomi yang rendah sehingga responden tidak siap untuk bertindak disebabkan karena kurangnya biaya. Pada penelitian lain yang dilakukan oleh Mientarini \& Yohanes (2018) di Jember dengan melibatkan 21 subjek penelitian juga menunjukkan hasil yang tidak signifikan antara sikap terhadap kepatuhan dengan $\mathrm{p}=0,321$ dan $\mathrm{r}=0,228$.

Hasil yang dilakukan oleh peneliti sesuai dengan penelitian yang dilakukan oleh Mweemba et al (2008) di Zambia dengan melibatkan 104 responden dewasa dengan rentang usia 18-66 tahun yang menunjukkan adanya hubungan yang signifikan antara sikap penderita TB Paru dengan kepatuhan minum obat. Penelitian lain yang dilakukan Wahyuni et al (2018) di 7 Puskesmas di kota Medan dengan melibatkan 100 responden penderita TB Paru dewasa menunjukkan adanya hubungan yang signifikan antara sikap dengan kepatuhan pengobatan. Hal ini dibuktikan dengan sikap yang baik akan meningkatkan kepatuhan pengobatan 3,7 kali lebih patuh dibandingkan dengan pasien yang memiliki sikap kurang baik.

Hasil dari domain sikap pada penelitian ini didukung oleh teori dari Notoatmodjo (2005) yang mengatakan bahwa sikap (attitude), merupakan reaksi atau respon yang masih tertutup dari seseorang terhadap suatu stimulus objek yang akan mempengaruhi perilaku seseorang. Berdasarkan teori diatas, hal ini menunjukkan bahwa domain sikap memiliki banyak pengaruh terhadap perilaku kesehatan termasuk kepatuhan pengobatan. Implikasi dari penelitian ini adalah pentingnya bagi petugas kesehatan khususnya pemegang program TB Puskesmas beserta kadernya untuk lebih memahami sikap individu pasien. Peningkatan sikap yang positif salah satunya dapat ditingkatkan dengan memberikan konseling yang baik untuk pasien TB Paru. Hasil dari penelitian ini menunjukkan kesesuaian dengan penelitian di Botswana dalam Mweemba. et al (2010) dimana 
sikap yang positif akan mengarah pada kesesuaian perilaku pencarian kesehatan (health seeking behavior) dan persepsi yang seharusnya didorong dan ditingkatkan pada pasien untuk mendorong seseorang dalam usahanya menuntaskan pengobatan.

Pada uji hipotesis korelasi antara variabel tindakan dengan kepatuhan menunjukkan bahwa terdapat korelasi yang bermakna. Penelitian ini selaras dengan penelitian di India yang dilakukan oleh Gopalakrishnan \& Umadevi (2018) pada 20 desa di daerah Tamil, Nadu dengan subjek penelitian berjumlah 400 orang. Pada penelitian ini menunjukkan bahwa adanya hubungan yang bermakna dan signifikan secara statistik antara tindakan dengan kepatuhan pengobatan pada pasien TB.

Adanya korelasi antara tindakan dengan kepatuhan ini juga selaras dengan teori perilaku yang dikemukakan oleh Notoatmodjo (2005) yang mengatakan bahwa perilaku manusia merupakan tindakan atau aktifitas dari manusia itu sendiri. Perilaku terbentuk dalam 3 domain sesuai dengan tujuan pendidikan yaitu pengetahuan, sikap dan tindakan. Setelah seseorang mengetahui stimulus atau objek kesehatan kemudian seseorang tersebut mengadakan penilaian atau pendapat terhadap apa yang diketahui, proses selanjutnya diharapkan seseorang akan melaksanakan atau mempraktekkan apa yang diketahui atau disikapinya.

Keterbatasan penelitian ini: pertama penelitian ini dilakukan saat pandemi Covid-19. Dampaknya adalah rentang waktu pengambilan sampel yang kurang dan protokol kesehatan yang harus diterapkan dengan mengurangi kontak dengan orang lain menyebabkan terhambatnya proses wawancara secara langsung sehingga peneliti hanya bisa mengambil data melalui via telepon. Kedua, keterbatasan variabilitas data dimana responden penelitian mayoritas berada pada fase awal pengobatan. Ketiga, penelitian ini menganalisis korelasi perilaku dari 3 domain yang terdiri dari pengetahuan, sikap, dan tindakan, sehingga tidak mencangkup faktorfaktor lain yang juga dapat mempengaruhi kepatuhan dari pasien. Keempat tidak dilakukan observasi pada pasien TB 01 dan TB 02 untuk menilai kepatuhan.
Hasil dari penelitian ini menunjukkan tindakan yang baik dari penderita TB Paru memiliki kepatuhan pengobatan yang baik juga. Hal ini menggambarkan kebutuhan yang dirasakan untuk melakukan tindakan dipengaruhi oleh stimulus yang memengaruhi persepsi seseorang dan akibatnya secara tidak langsung akan mempengaruhi perilaku kesehatannya salah satunya adalah kepatuhan terhadap pengobatan TB Paru.

\section{Kesimpulan}

Dari hasil penelitian yang telah dilakukan, dapat disimpulkan bahwa pada penelitian ini terdapat terdapat hubungan yang signifikan antara sikap dan tindakan dengan kepatuhan minum obat serta tidak adanya hubungan yang signifikan antara pengetahuan dengan kepatuhan minum obat pada pasien penyakit tuberkulosis paru di wilayah kerja puskesmas Cakranegara periode Juli sampai dengan November 2020.

\section{Ucapan terima kasih}

Kami Berterimakasih kepada segala pihak yang ikut berkontribusi dalam penyelesaian penelitian ini.

\section{Referensi}

Dinas Kesehatan Provinsi NTB (2019) Profil kesehatan Provinsi Nusa Tenggara Barat tahun 2018. Mataram, Indonesia, Dinas Kesehatan Provinsi NTB.

Farhat, M. R., Shapiro, B. J., Kieser, K. J., Sultana, R., Jacobson, K. R., Victor, T. C \& Murray, M. (2013). Genomic analysis identifies targets of convergent positive selection in drug-resistant Mycobacterium tuberculosis. Nature genetics, 45(10), 1183-1189.

Gopalakrishnan, S., \& Umadevi, R. (2018). Knowledge, attitude and practices regarding pulmonary tuberculosis in a rural area of Tamil Nadu, India: a cross sectional study. International Journal of Community Medicine and Public Health, 
5(9), 4055.

Green, LW. K. (2004). Health program planning: an educational and ecological approach.

Hendesa, A., \& Yan, S. T. (2018). Hubungan pengetahuan, sikap, dan dukungan keluarga dengan kepatuhan berobat pada pasien tuberkulosis paru di RS Paru Kota Palembang. Majalah Kedokteran Sriwijaya, 50(4), 175-184.

Mientarini, E. I., Sudarmanto, Y., \& Hasan, M. (2018). Hubungan Pengetahuan dan Sikap Terhadap Kepatuhan Minum Obat Pasien Tuberkulosis Paru Fase Lanjutan Di Kecamatan Umbulsari Jember. IKESMA, 14(1), 11-18.

Mushtaq, M. U., Majrooh, M. A., Ahmad, W., Rizwan, M., Luqman, M. Q., Aslam, M. J., ... \& Shad, M. A. (2010). Knowledge, attitudes and practices regarding tuberculosis in two districts of Punjab, Pakistan. The international journal of tuberculosis and lung disease, 14(3), 303. https://www.researchgate.net/profile/Muh ammad_Majrooh/publication/41407473

Mweemba, P., Haruzivishe, C., Siziya, S., Chipimo, P., Cristenson, K., \& Johansson, E. (2008). Knowledge, attitudes and compliance with Tuberculosis treatment, Lusaka, Zambia. Medical Journal of Zambia, 35(4).

file:///C:/Users/ASUS/Downloads/56064Article\%20Text-94729-1-10-

20100701.pdf

Notoatmodjo, S. (2005). Promosi kesehatan teori dan aplikasi. Jakarta: Rineka Cipta, 52-54.

Pandia, P., Syafiuddin, T., Bachtiar, A., \& Rochadi, K. (2019). The Relationship between Concordance Behaviour with Treatment Compliance and Quality Of Life of Patients with Pulmonary Tuberculosis in Medan. Open Access Macedonian Journal of Medical Sciences, 7(9), 1536. https://www.ncbi.nlm.nih.gov/pmc/article
s/PMC6542389/

Sari, I. D., Mubasyiroh, R., \& Supardi, S. (2016). Hubungan pengetahuan dan sikap dengan kepatuhan berobat pada pasien TB paru yang rawat jalan di Jakarta tahun 2014. Media Penelitian dan Pengembangan Kesehatan, 26(4), 243-248.

Tachfouti, N., Slama, K., Berraho, M., \& Nejjari, C. (2012). The impact of knowledge and attitudes on adherence to tuberculosis treatment: a case-control study in a Moroccan region. Pan African Medical Journal, 12(1).

https://www.ajol.info/index.php/pamj/arti cle/view/82681

Wahyuni, A. S., Soeroso, N. N., Wahyuni, D. D., Amelia, R., \& Alona, I. (2018). Relationship of Attitudes and Perceptions with Adherence in Treatment of Pulmonary Tuberculosis Patients in Medan, Indonesia.

World Health Organization. (2019). WHO guidelines on tuberculosis infection prevention and control: 2019 update (No. WHO/CDS/TB/2019.1). World Health Organization. 